\title{
上顎洞のいわゆる癌肉腫の一例
}

\author{
毛利 光宏・毛利学 - 西尾 正寿 \\ 島津董・平野 雅彦*・岡田聡**
}

\section{A Case of So-called Carcinosarcoma of the Maxillary Sinus}

\author{
Mitsuhiro Mohri, Manabu Mohri, Masatoshi Nishio, \\ Kaoru Shimazu and Masahiko Hirano \\ (Osaka Dental University) \\ Satoshi Okada \\ (Kobe University)
}

The patient was a 48-year-old woman who had complained of maxillary toothache. The radiologic impression was a tumor of the right maxillary sinus with bone destruction. After surgical removal of the tumor, we treated her with radiotherapy and chemotherapy.

Histpathological examination showed so-called carcinosarcoma consisting mainly of sarcomatous spindle cells and also of islands of squamous cell carcinoma. In places, transitions between squamous cell carcinoma and sarcomatous spindle tumor cells were found. Therefore, we diagnosed the case as the spindle cell squamous carcinoma.

The maxillary sinus is an uncommon site for so-called carcinosarcoma. Surgical excision is the most suitable primary therapy for so-called carcinosarcoma of the maxillary sinus.

Key words: carcinosarcoma, spindle cell squamous carcinoma, pseudosarcoma

緒言

墨性上皮性腫瘍之昰性間質腫瘍が同一腫瘍中 に混在する疾患を癌肉腫之呼ぶが，その histogenesisについては議論の多いとてろである. このような疾患は一般に子宮, 乳腺, 甲状腺, 食道などに多く，上顎洞においては数(例茥 ${ }^{(9)}$ が 報告されているのみである. 最近われわれは上 顎洞に発生した癌肉腫様組織像を持つ spindle cell squamous carcinoma の一症例を経験し たので，いわゆる癌肉腫に対する診断基準につ いての文献的考察を加えて報告する.

\section{症例}

患者：48才 女性

主訴：右上顎歯痛, 鼻根部痛

家族歷・既往歷：特記すべきととなし

現病歴：炤和 59 年 2 月より右上顎䨑痛, 鼻根 
部痛，右鼻閉が出現した。ときに血性鼻漏も出 現してきたため, 同年 4 月 2 日本院歯科受診後 当科老受竞した。

初診時所見：右煩部は軽度腫脹し，右上顎結 節之眼窩下縁に压痛を認めた。右鼻腔内では中 鼻道から総鼻道にか汁てポリープ上肉芽様病変 を認めた。膿汁等分泌物は認めず，頸部リンパ 節は触知しなかった。

副鼻腔 $\mathrm{X}$ 線所見：単純撮影では，右上顎洞の 片側性混濁之TM線の消失，右篩骨洞混濁老認 めた，断層撮影では，穊骨洞から鼻腔に充満す る腫焬陰影を認めた（図 1 )。 C T 検查では上 顎洞後壁の広範な少火損老認め，覀性腫瘍が疑 われた（図 2 ).

手術所罗：鼻内ポリープと上顎润狖巣の生検 組織像では肉芽組織のみで思性所見は得られな かったが，臨床所見から琹性腫陽を否定できな いため，4月27日上頭润试験開洞を施行した。

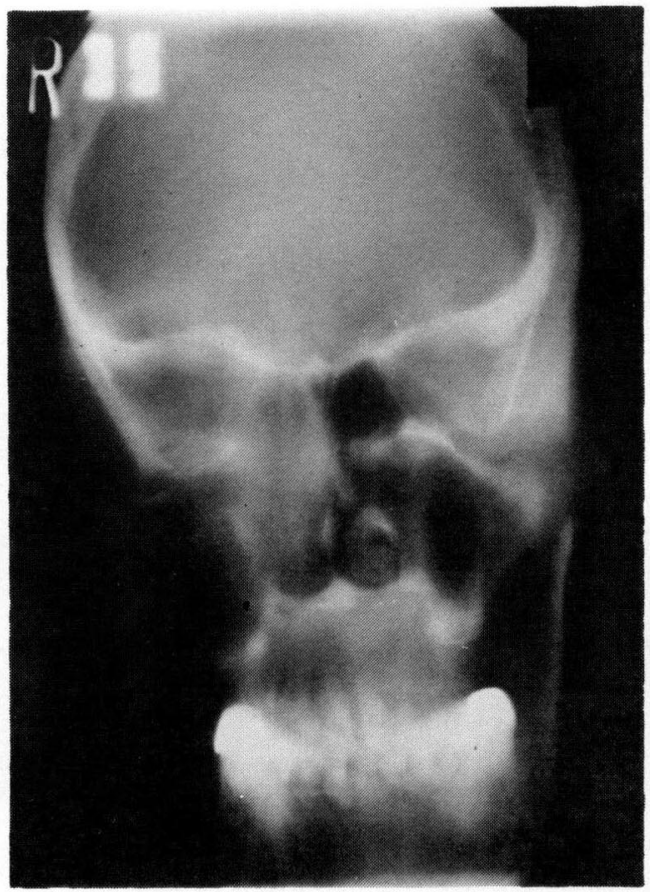

図 I断層撮影像 篩骨洞から卑腔に立満する腫湯陰影を 認める
犬霜窩を削開する之充実性の腫瘍が内压に押さ れるように洞内より突出し，骨壁上の境㖎屯明 瞭であり腫瘍の摘出術を行った（図 3 ）。上顎 洞後壁近くでは腫湯は柔く粘液腫状となってい た。 上顎洞後壁，眼窩下壁は広範围に火損して いたが，骨膜は破壊されていなかった。篩骨洞 を開放し，下鼻道側壁・下鼻甲介を摘出した。 術後, ${ }^{60}$ Co5000 rad 照射と 5 F U 2000mg動注療 法を行った。腫瘍は消失したが，7月12日局所 再発し同部に cryosurgery 1 回施行した。 術後10ケ月経過した现在，局所再発や遠隔転移 は認めていない。

病理組織学的伒罗：腫湯組織の大部分は紡錐 形の腫瘍細胞がびまん性に不棁剘汇増殖して肉 腫様の組織像を示しているが，上ころどころに 低分化～高分化型扁平上皮癌の像を示す細胞集

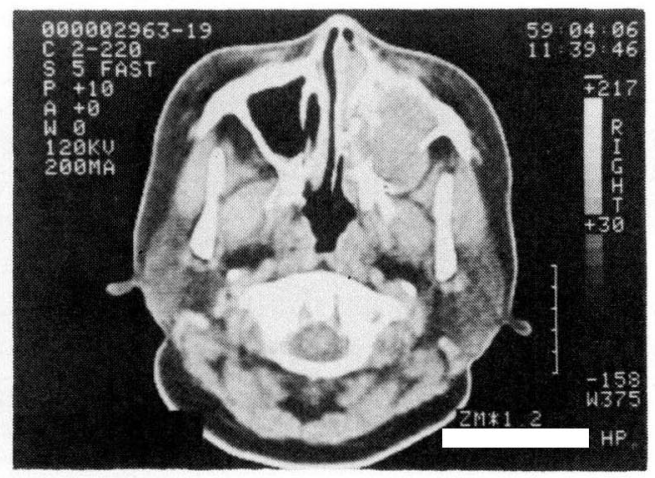

図 2 C T像 右上顎洞後壁の欠損を琶める

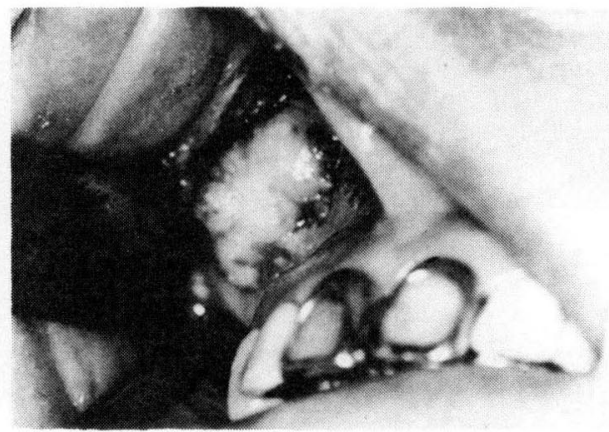

図 3 腫煌肉眼所見 前方は充実性で後方は粘液腫状を呈した。 


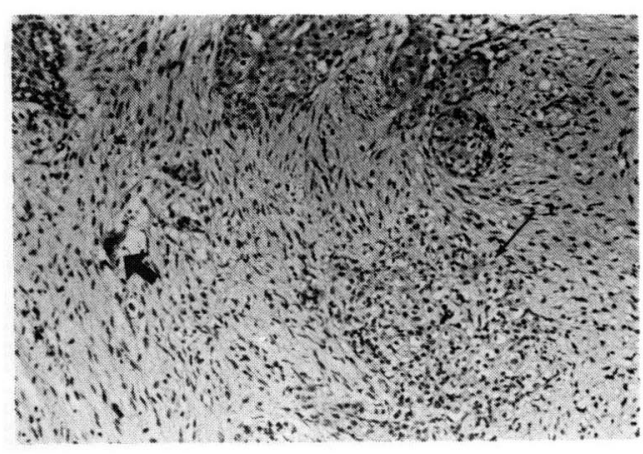

図 4 腫煬組織像. H・E染色 細矢印は扁平上皮癌細胞力ら紡鍾形細 胞への移行像．太矢印は P A S 陽性の 扁平上皮様腫揚細胞

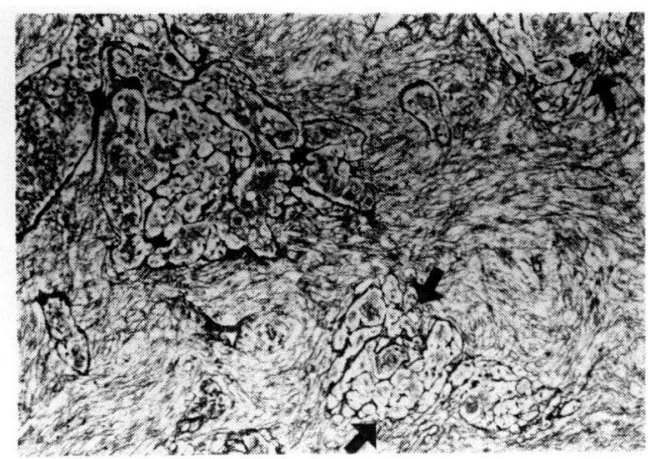

図 5 腫瑒組織像. 鍍銀染色

矢印は胞巣構造の破綻部で癌腫之肉腫 様部との移行に相当する

団が明瞭な胞宩を形成して島嶼状に散在してい る（図 4 ）。これらの扁平上皮癌の胞紧構造は 全般に境界が鮮明であるが，部位によっては胞 巣の周辺部がくずれて, 扁平上皮癌細胞が肉腫 椂の像を示す紡鉠非腫瘍練胞に移行している像 が認められる（図4）。このような部位では, 癌胞单の凮囲をとり囲んでいる太い好銀線維が 練くなり，かつ断裂して，鍍銀像においても胞 单構造の破綻が認められる（図 5 )。肉腫様の 紡鍾形腫瘍細胞は不規則に站に分卮して特定の 配列は示さず，細胞の同定は闲難であるが，と きに好酸性の胞体在有して細胞境界の比較的明 瞭な細胞が散見される（図 4 ）。このような紐 胞は扁平上皮澏練胞之同様に, 胞体内にP A S

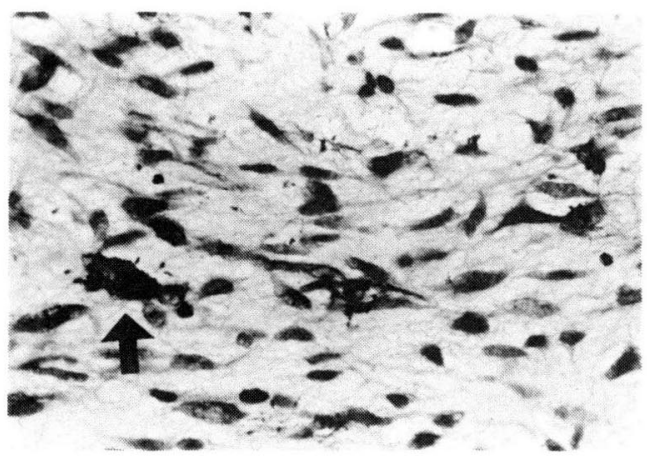

図 6 腫場組織像. P A S 染色 肉腫様像を示す部位で，矢印は P A S 陽性顆粒を有する扁平上皮様細胞

陽性物質が恐められ，恐らく扁头上皮紐胞へ分 化したものと推定される（図6）。これらの所 見加ら, 本腫瘍を癌肉腫㥞の像を示す扁平上皮 癌で, 肉腫様の部位は spindle cell squamous carcinoma と診断した。

\section{考按}

腫瘍組織が癌腫像上肉腫像との bimorphic pattern を示す埸合は癌肉腫之総称されるが, その肉腫像を示す部位のhistogenesisをめぐっ て種々の解釈がなされている．乙れまでに嵒肉 腫として跟告されている症例は，おおむね次の 3つに大別される.

(1)肉腫様絊胞む上皮由米で neoplastic

(2)肉腫様細胞は非上皮由来でnon-neoplastic

(3)肉腫様細胞は非上皮由来で neoplastic

(1)は癌細胞が極度の多態性を示すために肉腫 栐に見えるとするものである．Lichtiger ${ }^{10)}$ は 癌肉腫像を示す扁平上皮癌の壦合, 紡鉏形腫瘍 紼胞に未発達なデスモゾームを認めて上皮山束 の練胞と考え，てれ存 spindle cell squamous carcinoma と称している。 そして原因は不明だ が, デスモゾームとトノフィラメントの消火に より，間質の压維作:用で䙖紼胞が紡錘形になる としている．また，Appleman"11 も同様の所見 を squamous cell carcinoma with sarcomalike stroma として報告し, 肉腫様細胞上皮由 来としている. 
(2)は肉腫様紐胞は癌の刺激による結合組織の 二次的反応で非腫瘍性であるとするあのであ る. Lane ${ }^{12)}$ はその根拠として自発的転移能の 欠除を挙げ，肉腫様部位を pseudosarcoma 称している.

(3)は真性癌肉腫のことで，上皮成分も間質成 分も覀性化しているものである. Meyer ${ }^{13)}$ はこ れ在次の様に分類している. (1) collision tumor; 癌と肉腫が各々独立.して発生し, 偶然に組 み合わさったもの. (2)combination tumor ; 共 通の細胞型より上皮成分之間質成分が分化し, 各々が琹性化したもの. (3)composition tumor；上考性及び間質性成分が同時に泌性化し たもの. Saphir\& Vass ${ }^{14)}$ は153例の癌肉腫症例 を検討し, そのうちの3〜4例のみが真性癌肉腫 とみなしうるとし, 他はすべて primary carcinoma であると述べている。一j, Legier ${ }^{15}$ は真性癌肉腫の診断基準として次の 6 条件を挙 げている。

1. 覀性上皮性, 恶性間質性成分が同時に存 在する.

2. 密摆に混合しているにむかかわらず，雨 成分間に移行部が少られない。

3. reticulin 染色で肉腫㥞成分には明嘹な 網状線維構造を認めるが, 癌腫成分にはまった く認めない。

4. 奇形腫を思わせる組織成分が存在しな い.

5. 両成分の独立。した転移があれば，癌肉腫 の絶対的証拠となる.

6. 組織培養で上皮性及び間質性成分の明瞭 な增殖を認める。

さて，われわれの症例はこの晾断基準による と $1 ， 3 ， 4$ を満たすが，屚平上皮癌細胞之肉 腫様紡鍾形細胞との間に移行部があること, 紡 鍾形細胞中に扁平上皮様細胞を認めることよ り, 澏が肉腫様化した spindle cell squamous carcinoma に相当するむのと考えられる．吉 原”が報告するように，癌紐胞の明白なspindle cell への移行を認め机ば真性癌肉腫との鑑別は
容易だが、移行部が確認できない場合鑑別はむ ずかしくなる。したがって，ての種の腫湯を診 断する埸合，できるだけ多数の橒本で移行部の 有無を検索することが必要であり，また上皮成 分が認められず肉腫成分しか認めない場合で 屯, この spindle cell squamous carcinoma を念頭に㧈いて上皮成分の検索をしなければな らないといえる。そして，肉腫様細胞の histogenesis を決好るうで，光学顕微鏡レベル での診断には限界があり，川堀6) も述べるごと く最終的には電子顕微鏡学的検索に街たねばな らない，ての様に癌肉腫の診断特に早剘診断は むずかしい，それは，本邦で報告されている上 顎润真性癌肉腫 4 例(3)46)9) のうち，2 例 ${ }^{3 / 9)}$ が癌 腫として治療を開始され，治療中に癌腫中心の 腫瘍が肉腫中心に变化したてとで真性癌肉腫の 確定診断を得たことからもわかる.

癌肉腫の治療は真性癌肉腫之, pseudosarcoma, spindle cell squamous carcinoma で は異なるとされる。真性澏肉腫は，本邦の諸 例34)9 では肉腫成分が放射線治療に抵抗して增 殖するととから，手術療法が第一邀扑とされ る. これに対し pseudosarcoma こ spindle cell squamous carcinoma は癌腫としての治 療に準ずるとされる゙ .

spindle cell squamous carcinoma でとの ような癌の肉腫椂変化を米たす原因は，(1) X線 照射をはじめとする放射線の影蝗，(2)Cautery， あるいは Endothermy の影響, (3)局所異物 ${ }^{16)}$, (4)慢性炎症 ${ }^{1416)}$ があげられているが，われわれ の症例では(1)〜 (4)の既往は特に誌められていな い.しかし，放射線が何らかの誘因になるとす れば，放射線治療は肉腫様変化を促進させる恐 れもあり, 病理組織診断上の困難さも考えると 牛呂9) 屯述べているように，いわゆる癌肉腫疾 患の治療は手術療法を主とし，放射線治療・化 学療法は従とする方がよいと考える.

\section{結語}

上顎润の spind̉le cell squamous carcinoma の一症例を報告した。いわゆる癌肉腫について 
文献的に考察し，その診断基集について検討し た。

\section{参考文献}

1) Traina $\mathrm{S}:$ Carcino-sarcoma del seno Mascellare. Tumori II: 36〜43, 1924.

2) Meyer I and Shklar G : Carcinosarcoma of the maxillary sinus. OS OM and OP 10 : 1065 1074, 1957.

3 ）松井道夫：上顎洞に発生した真性癌肉腫の一例. 耳鼻 19: 113 120, 1973.

4 ）松岡秀樹：上顎洞真性癌肉腫の一例. 癌の臨床 $20: 408 \sim 412,1974$.

5 ) Howell JH, et al : Spindle cell carcinoma of the nose and paransal sinuses. Surgical Forum $29: 565 \sim 568,1978$.

6）川堀真一：上顎洞之喉頭の癌肉腫 2 症例. 耳鼻臨 床 $72: 635 \sim 643,1979$.

7 ）吉原俊雄：上顎洞に発生した spindle cell squamous carcinomaの一例. 耳喉 $54: 731 \sim 734$, 1982.

8) Feinmesser R, et al : Carcinosarcoma of the nose and paranasal sinuses - a case report. Rhinology 20:167 170, 1982.

9 ) 牛呂公一：上顎洞真性癌肉腫. 耳喉 $55 ： 529$ 533, 1983.
10) Lichtiger $B$, et al : Spindle-cell variant of squamous carcinoma. A light and electron microscopic study of 13 cases. Cancer 26 : 1311 1320, 1970.

11) Appleman $H$ and Oberman $H:$ Squamous cell carcinoma of the Larynx with sarcoma-like stroma. Am J Clin Path $44:$ 135 145, 1965.

12) Lane $\mathrm{N}$ : Pseudosarcoma (poly poid sarcoma-like masses) associated with squamous-cell carcinoma of the mouth, fauces, and larynx. Cancer 10:19 41, 1957.

13) Meyer $R$ : Beitrag zur verstandigung uber die Namengebung in der Geschwulstlehre. Centralbl f Allg Path u Path Anat $30: 291 \sim 296$, 1919.

14) Saphir $O$ and Vass A : Carcinosarcoma. Amer J Cancer $33:$ 331 361, 1938.

15) Legier JF : Carcinosarcoma of the upper respiratory tract. Ann Otol $71: 173 \sim 186,1962$.

16）渡辺道郎：癌の肉腫梯変化について. 癌の臨床 $5: 457 \sim 461,1959$.

原稿到着：昭和 60 年 7 月 11 日 別刷請求先：毛利光宏 厂650 神戸市中央区楠町 $7-5-2$ 神戸大学矢学部耳鼻咽喉科学教室 